\title{
PERKAWINAN BEDA AGAMA
}

\section{Abstraksi:}

Perkawinan bertujuan untuk membina keluarga sakinah mawaddah dan rahmah. Dalam usaha mewujudkan tujuan tersebut, Islam menawarkan keserasian antara pasangan, yakni sepadan baik dalam strata sosial ataupun keyakinan yang sama. Walau kenyataannya keyakinan tidak bisa menjadi jaminan terwujudnya tujuan perkawinan. Berbeda dengan perkawinan campuran dalam agama dan undang-undang yang tidak dianggap sebagai masalah, dalam perkawinan beda agama, baik dalam agama maupun undang-undang, terdapat beberapa penafsiran. Menurut Islam, perkawinan dengan orang musyrik dan kafir merupakan masalah besar. Lain halnya dengan Ahli Kitab, sesuai dengan apa yang ada dalam al-Qur'an dan telah dipraktikkan Rasulullah.Berkenan hal tersebut penulis mencoba mengurai beberapa ayat-ayat al Qur'an yang menbahas tentang perkawinan beda agama dengan menjabarkan pembahasan sebagai berikut; Pengertian Perkawinan Antar-agama, Nas tentang Perkawinan antar-Agama(wanita musyrik), Perkawinan antar-Agama di Masa Nabi saw, Maqasid alSyari'ah Nas-Nas Perkawinan Beda Agama, Pernikahan beda agama perspektif Fikih Konvensional, Perkawinan Beda Agama di Indonesia, Peraturan tentang Perkawinan antar-Agama di Negara Muslim Lain (Kontemporer), dan Analisis Kawin beda agama dalam praktekIslam akan menjadi keniscayaan di setaip aspek yang akan dibahas di bawah ini.

Keyword: ahlu kitab, Maqasid al-Syari'ah, sadd az-zari'ah

Zainal Arifin, M.Pd.I

Dosen PAI STAI Miftahul 'Ula dan Ketua LP Ma'arif NU Nganjuk zain_nisa@yahoo.co.id 


\section{A. Pengertian Perkawinan Antar-agama}

Meski tidak ada rumusan pasti tentang Perkawinan antaragama dalam UU Perkawinan, kita bisa merujuk pada berbagai definisi para sarjana. ${ }^{1}$ Pertama, menurut Rusli dan R. Tama, perkawinan antar-agama adalah ikatan lahir batin antara seorang pria dan wanita yang, karena berbeda agama, menyebabkan tersangkutnya dua peraturan yang berlainan tentang syarat-syarat dan tata cara pelaksanaan perkawinan sesuai dengan hukum agamanya masing-masing, dengan tujuan untuk membentuk keluarga bahagia dan kekal berdasarkan ketuhanan Yang Maha Esa.

Kedua, menurut Ketut Mandra dan I. Ketut Artadi, perkawinan antar-agama adalah ikatan lahir batin antara seorang pria dengan wanita yang masing-masing berbeda agamanya dan mempertahankan perbedaan agamanya itu sebagai suami istri dengan tujuan untuk membentuk rumah tangga yang bahagia dan kekal berdasarkan Ketuhanan Yang Maha Esa. Ketiga, menurut Abdurrahman, perkawinan antar-agama adalah suatu perkawinan yang dilakukan oleh orang-orang yang memeluk agama dan kepercayaan yang berbeda satu dengan yang lainnya.

Dari pengertian di atas, menurut hemat penulis, perkawinan antar-agama merupakan hubungan dua insan yang berbeda keyakinan dan diikat dalam satu pertalian yaitu perkawinan. Ada dua unsur pokok yang harus ada dalam definisi perkawinan antaragama, yaitu keyakinan atau memeluk agama yang berbeda dan diikat dalam suatu hubungan perkawinan.

\section{B. Nas tentang Perkawinan antar-Agama(wanita musyrik)}

Di dalam al-Qur'an dan Hadis, perkawinan dengan beda keyakinan masih diperdebatkan, meski terdapat pengecualian untuk Ahli Kitab. Hal ini disebutkan dalam beberapa ayat dalam al-Qur'an, antara lain:

${ }^{1}$ O.S. Eoh, Perkawinan antar-Agama dalam Teori dan Praktek (Jakarta: PT. Raja Grafindo Persada, 1996), hlm. 35 
1. Surat Al-Baqarah ayat 221

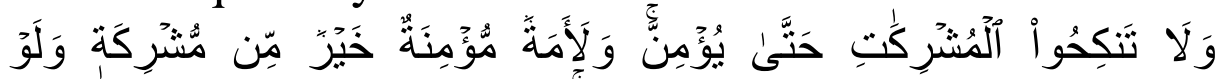

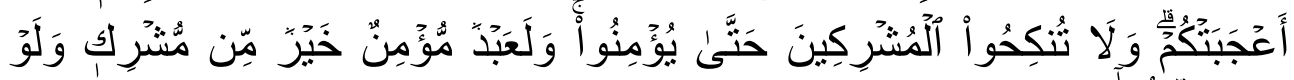

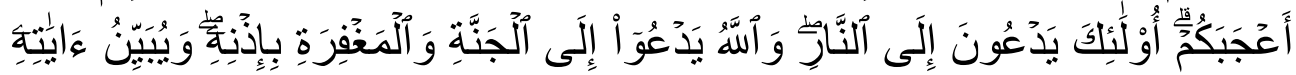

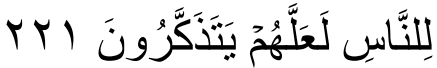

"Dan janganlah kamu menikahi wanita-wanita musyrik, sebelum mereka beriman. Sungguh, hamba sahaya wanita yang mukmin lebih baik dari wanita musyrik, walaupun dia menarik hatimu. Dan janganlah kamu menikahkan orangorang musyrik (dengan wanita-wanita mukmin) sebelum mereka beriman. Sungguh, hamba sahaya yang mukmin lebih baik dari orang musyrik, walaupun dia menarik hatimu. Mereka mengajak ke neraka, sedangkan Allah mengajak ke surga dan ampunan dengan izin-Nya. Dan Allah menerangkan ayat-ayat-Nya (perintah-perintah-Nya) kepada manusia supaya mereka mengambil pelajaran."

Ayat tersebut menjelaskan bahwa; orang musyrik dan kafir tidak boleh dinikahi oleh orang Muslim, demikian pula Ahl Kitab pada zaman sekarang, karena dianggap melenceng dari ayat tersebut. Pada zaman dulu mereka sudah mengakui bahwa Nabi Isa sebagai anak Allah (untuk orang Nasrani) dan Uzair sebagai anak Allah (untuk orang Yahudi), artinya mereka sudah kafir. Maka Ahl Kitab tidak diperkenankan menikahi wanita mukmin, demikian pula sebaliknya pria mukmin tidak boleh menikahi Ahl Kitab.

Kata musyrikah dalam al Qur'an yang mempunyai makna senada dengan ayat ini ialah firman Allah QS. Al Baqarah; $105 .^{2}$

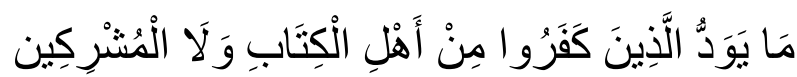

“orang-orang kafir dari ahli kitab dan orang-orang musyrik tiada menginginkan (diturunkannya suatu kebaikan kepadamu dari tuhan).... (QS.al Baqarah: 105)”

\footnotetext{
${ }^{2}$ Ahmad Mustofa al Maragi, Tafsir al Maragi (Mesir Al Babi Al Habibi, 1394H/1974) terj. K.Anshori Umar Sitanggal dkk) hlm.262
} 
Dan firman Allah yang lain :

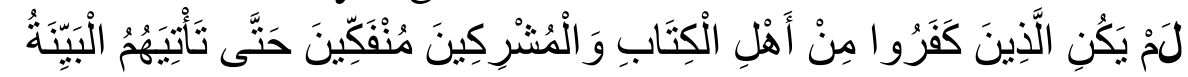

"orang-orang kafir yahni ahli kitab dan orang-orang musyrik (mengatakan bahwa mereka) tidak akan meninggalkan (agamanya) sebelum datang kepada mereka bukti yang nyata." (QS. Al Bayyinah, 98;1)

Dari beberapa ayat tersebut dapat ditarik benang merah bahwa janganlah kalian menikahi wanita-wanita musyrik, selama mereka masih berada dalam kemusyrikatannya.

Dalam perspektif historisnya, asbab al-nuzul surat AlBaqarah 221 tersebut menjadi polemik di kalangan ahli tafsir al-Qur'an dari generasi ke genarasi. Hal ini dipicu oleh adanya dua periwayatan yang berbeda mengenai sebab turunnya ayat tersebut. ${ }^{4}$

Pertama, Ibnu al-Munzhir, Ibnu Abi Hatim, dan al-Wahidi dari Muqatil meriwayatkan bahwa ayat ini diturunkan berkaitan dengan kasus Abu Martsad al-Ghanawi atau Martsad bin Abi Martsad, seorang laki-laki anggota persekutuan Bani Hasyim yang diutus Rasulullah ke Makkah untuk membantu mengevakuasi orang-orang Muslim secara rahasia. Dahulu, ketika masih jahiliyah (di Makkah), ia memeliki seorang kekasih bernama Inaq. Tapi, setelah masuk Islam Martsad meninggalkan kekasihnya tersebut. Pada suatu saat, kekasihnya mendatangi Martsad dan menanyakan alasan mengapa ia meninggalkannya. Martsad menjawabnya dengan mengatakan bahwa Islam melarang hubungan kita sambil menegaskan bahwa ia akan meminta izin pada Rasulullah untuk mengawininya. Mendengar jawaban itu, Inaq kecewa, menjerit, dan datanglah orang-orang memukuli Martsad dengan pukulan keras lalu membiarkannya pergi. Setelah menyelesaikan

3 Depag RI, al Qur'an dan terjemah (Gema Risalah press Bandung, 1989)

${ }^{4}$ Suhadi, Kawin Lintas Agama Perspektif Kritik Nalar Islam (Yogyakarta: LKiS, 2006), hlm. 22. 
tugasnya di Makkah dia menghadap Rasulullah saw. dan meminta izin untuk mengawini Inaq. Lalu turunlah ayat ini. ${ }^{5}$

Kedua, al-Wahidi meriwayatkan dari jalur al-Suddi dari Malik dari Ibnu Abbas, dia berkata, "Ayat ini berkaitan dengan seorang sahabat Abdilah bin Rawahah yang datang kepada Rasulullah menceritakan perbuatannya yang telah memukul hamba perempuannya yang berkulit hitam kelam dan jelek karena marah. Dia merasa menyesal dan meminta petunjuk Rasulullah." Rasulullah bertanya, "Bagaimana keadaan hamba sahaya tersebut?" Abdillah menjawab bahwa budaknya itu seorang muslimah yang taat. Rasulullah kembali berkata, "Wahai Abdillah, dia itu adalah seorang yang beriman". Maka Abdilah menimpali, "Demi Zat yang mengutusmu dengan hak, aku akan memerdekakannya dan menikahinya". Peristiwa tersebut memancing penghinaan dan rasa sinis dari masyarakat, karena menganggap Abdillah menikahi budaknya yang hina dan jelek. Sehubungan dengan hal tersebut turunlah wahyu Allah tersebut. ${ }^{6}$

2. Surat al-Mumtahanah ayat 10

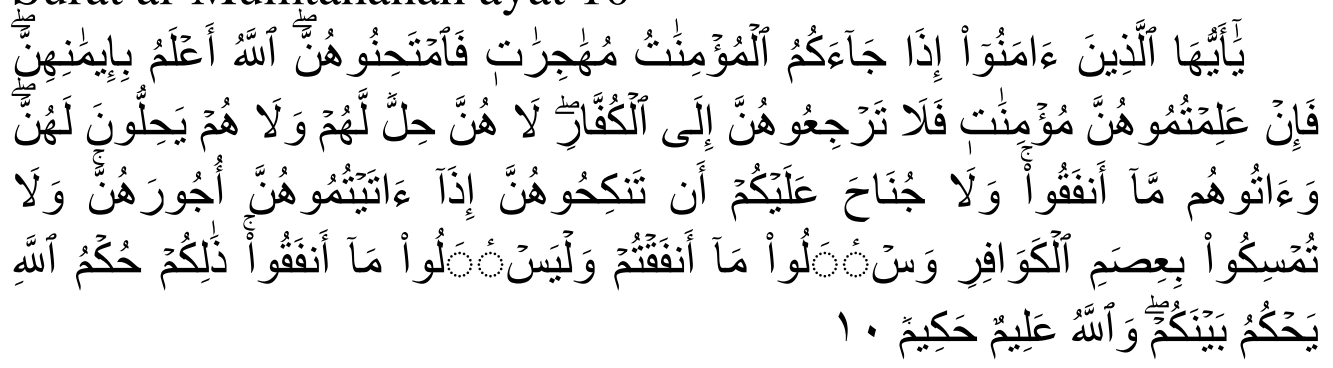

"Wahai orang-orang yang beriman, apabila datang berhijrah kepadamu perempuan-perempuan yang beriman, maka hendaklah kamu uji (keimanan) mereka. Allah lebih mengetahui tentang keimanan mereka; maka jika kamu telah mengetahui bahwa mereka (benar-benar) beriman, maka janganlah kamu kembalikan mereka kepada (suamisuami mereka) orang-orang kafir. Mereka tiada halal bagi

\footnotetext{
${ }^{5}$ Muhammad Rasyid Rid \}a, Tafsir al-Manar, jilid II (Beirut: Dar al-Fikr, 1957), hlm 247.

${ }^{6}$ Al-Wahidi, Asbab al-Nuzul (Kairo: Dar al-Ittih \}ad al-'Arabi li al-Tab'ah, 1968), hlm. 45 .
} 
orang-orang kafir itu dan orang-orang kafir itu tiada halal pula bagi mereka. Dan berikanlah kepada (suami-suami) mereka mahar yang telah mereka bayar. Dan tiada dosa atasmu mengawini mereka apabila kamu bayar kepada mereka maharnya. Dan janganlah kamu tetap berpegang pada tali (perkawinan) dengan perempuan-perempuan kafir; dan hendaklah kamu minta mahar yang telah kamu bayar; dan hendaklah mereka meminta mahar yang telah mereka bayar. Demikianlah hukum Allah yang ditetapkanNya di antara kamu. Dan Allah Maha Mengetahui lagi Mahabijaksana."

Ayat di atas menyiratkan bahwa adanya larangan meneruskan tali perkawinan dengan wanita-wanita musyrikah dan kafir, yang saat itu masih dalam ikatan laki-laki Muslim. ${ }^{8}$

3. Surat al-Ma'idah ayat 5

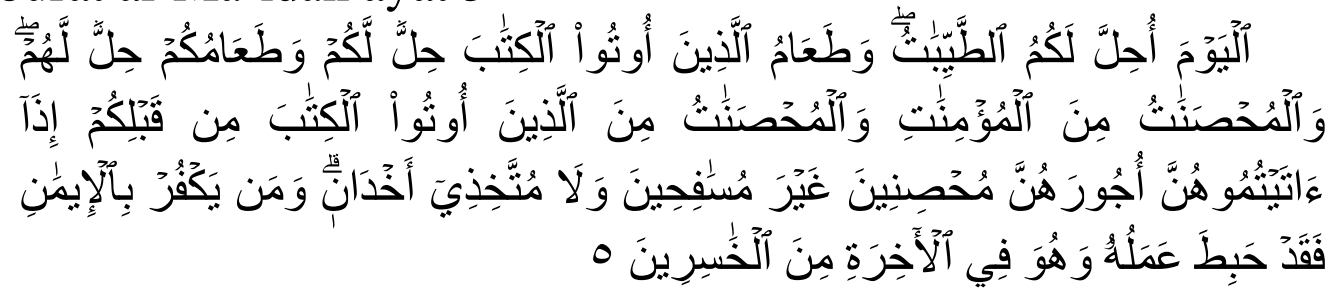

"Pada hari ini dihalalkan bagimu yang baik-baik. Makanan (sembelihan) orang-orang yang diberi Alkitab itu halal bagimu, dan makanan kamu halal (pula) bagi mereka. (Dan dihalalkan mangawini) wanita yang menjaga kehormatan (wanita merdeka) di antara wanita-wanita yang beriman dan wanita-wanita yang menjaga kehormatan di antara orang-orang yang diberi Alkitab sebelum kamu, bila kamu telah membayar maskawin mereka dengan maksud menikahinya, tidak dengan maksud berzina dan tidak (pula) menjadikannya gundik-gundik. Barangsiapa yang kafir sesudah beriman (tidak menerima hukum-hukum Islam), maka hapuslah amalannya dan ia di hari kiamat termasuk orang-orang merugi."

\footnotetext{
${ }^{7}$ Depag RI, al Qur'an dan terjemah (Gema Risalah press Bandung, 1989)

${ }^{8}$ Abdul Mutaal Muhammad Al-Jabry, Pernikahan Campuran Menurut Pandangan Islam, terj. Achmad Sathori (Jakarta: PT. Bulan Bintang, 1988), hlm. 39

9 Depag RI, al Qur'an dan terjemah (Gema Risalah press Bandung, 1989)
} 
Dari ayat di atas bisa disimpulkan bahwa wanita Muslimah tidak boleh menikah dengan pria non-Muslim, termasuk dengan Ahl Kitab. Pria Muslim pun tidak boleh menikahi wanita kafir/musyrik, tapi pria Muslim boleh menikahi wanita Ahl Kitab. Ahl kitab adalah penganut agama Yahudi dan Nasrani (Kristen). ${ }^{10}$

Menanggapi nas yang membahas perkawinan antar-agama, Umar Farukh, seorang pemikir modern, dan beberapa ahli tafsir menilai bahwa ayat 221 surat al-Baqarah dan ayat 10 surat alMumtahanah di-nasakh oleh ayat 5 surat al-Ma'idah. Maka, diperbolehkan bagi laki-laki Muslim menikahi wanita kitabiyah atau Ahli Kitab, karena hukum pengharaman mutlaknya telah di-naskh. ${ }^{11}$

Sementara itu, menurut Ibnu Hazm, wanita-wanita Ahli Kitab merupakan pengecualian sekelompok kecil dari jumlah besar wanita kafir. Menurut sebagian ahli tafsir, masalah ini bukan termasuk naskh melainkan pen-takhsis-an (pengkhususan). Pendapat ini kemudian sejalan dengan pendapat Ibnu Hazm yang memperbolehkan pernikahan dengan wanita Ahli Kitab. ${ }^{12}$

Rasyid rida mislanya, menyebutkan bahwa; Majusi, Buhda, Hindu, Konghuchu, Shinto juga merupakan ahl al-kitab yang menganut ajaran tauhid. ${ }^{13}$ Pendapat ini tampaknya berseberangan dengan pendapat kebanyakan ulama yang diketahui selama ini. Sebagaimana Ridha, Ibnu Hazm, menyebutkan bahwa majusi menurut sebagaian ulama salaf seperti Ali dan Hasan al-Bashri, juga merupakan ahl al-kitab, karena Ibnu Hazm memperbolehkan pria muslim mengawini

\footnotetext{
${ }^{10}$ Miftah Faridl, Masalah Nikah dan Keluarga (Jakarta: Gema Insani Press, 1999), hlm. 21

${ }^{11}$ Abdul Mutaal Muhammad Al-Jabry, Pernikahan Campuran Menurut Pandangan Islam, hlm. 40

12 Ibid.

${ }^{13}$ Rasyid Ridha, Tafsir al-manar, VI,Mesir,1952. 193
} 
wanita majuzi. ${ }^{14}$ Sementara Quraish Shihab menyatakan bahwa ahl al-kitab sebagaimana yang dimaksud adalah dari golongan kristen dan Yahudi, namun golongan selain mereka seperti para penyebah berhala non Arab dan sebagainya dapat diperlakukan sama dengan ahl al-kitab. ${ }^{15}$

\section{Perkawinan antar-Agama di Masa Nabi saw.}

Perempuan musyrikah tidak boleh dinikahi Pria Muslim tetapi boleh menikahi perempuan Ahli Kitab. Sedangkan perempuan Muslimah tidak boleh dinikahi pria musryik walaupun pria itu Ahli Kitab. Alasannya, mengikuti Rasul saw. yang memiliki dua istri Ahli Kitab yakni Safiyah binti Huyay bin Aktab $^{16}$ dan Mariatul Qibtiyah. ${ }^{17}$ Diamnya Rasulullah dari menetapkan syarat Islamnya wanita kitabiyah ketika dinikahi oleh orang Muslim, karena beliau menganggap hal itu sudah biasa terjadi. ${ }^{18}$

Dalam menghalalkan makanan orang Ahli Kitab, Allah tidak memberikan suatu batasan, tetapi berlaku umum baik makanan Ahli Kitab sebelum diutus Nabi Muhammad saw. ataupun sesudahnya. Sedangkan dalam menghalalkan kawin dengan Ahli Kitab, Allah memberikan batasan dengan suatu ketentuan "Ahli Kitab sebelum kamu (Muhammad)". Jadi, Ahli Kitab yang boleh dikawini adalah Ahli Kitab yang telah memeluk agamanya

${ }^{14}$ Ibnu Hazm, al muhallah, vi,Bairut;dar-al fikr. 449

${ }^{15}$ M. Qurais Shihab, Ahli kitab dalam Wahyu Nafis, ed. Rekontruksi dan religius Islam (Jakarta;Paramadina,1969). 126

${ }^{16}$ Safiyah adalah istri Kinanan bin Rabi' yang mati dalam Perang Khaibar, putri pimpinan Yahudi dan pembesar suku Bani Nadlir ini merupakan tawanan Perang Khaibar yang tertawan dan dihadapkan kepada Rasulullah saw. Ia diberikan dua pilihan oleh Rasulullah saw., masuk Islam kemudian dinikahi beliau atau memperoleh kemerdekaan dan dipulangkan menemui kaumnya. Akhirnya ia memilih masuk Islam dan dinikahi Rasulullah saw., kemerdekaan Shafiyah dijadikan sebagai maskawin oleh Rasulullah.

${ }^{17}$ Mariatul Qibtiyah adalah budak Rasulullah saw. yang dihadiahkan oleh Muqauqis kepada beliau, Rasulullah saw. telah mendapatkan seorang anak laki-laki darinya sewaktu ia menjadi selir beliau atau sebelum dikawin. Dan berhubungan dengan selir yang masih budak diperbolehkan secara mutlak, tetapi akhirnya ia masuk Islam.

${ }^{18}$ Abdul Mutaal Muhammad Al-Jabry, Pernikahan Campuran Menurut Pandangan Islam, hlm. 126. 
sebelum Nabi Muhammad diutus. Hal ini sesuai dengan praktik Nabi saw. terhadap kedua istrinya yang Ahli Kitab itu. ${ }^{19}$

\section{Maqasid al-Syari'ah Nas-Nas Perkawinan Beda Agama}

Dilakukannya perkawinan antar-agama adalah untuk mengajak agama lain khususnya Ahli Kitab untuk masuk dan memeluk agama Islam. Menjalin hubungan dengan kesadaran toleransi antar-pemeluk agama, dengan cara pria Muslim menikahi perampuan Ahli Kitab. Karena biasanya pria lebih kuat dan bisa metolelir wanita Ahl Kitab dalam menjalankan agamanya (Islam mengakui Isa a.s. sebagai Nabi Allah, sedangkan Ahl Kitab tidak mengakui Muhammad saw. sebagai Rasul). ${ }^{20}$

Dengan demikian, akan timbul hubungan diplomasi antara pihak Muslim dengan Ahli Kitab. Lambat laun mereka akan sadar dengan keberadaan dan keyakinan yang dipegang selama ini. Walaupun tanpa adanya paksaan mereka akan masuk Islam dengan sendirinya sehingga terciptalah suatu tujuan Islam sebagai agama rahmatan li al-alamin.

\section{E. Pernikahan beda agama perspektif Fikih Konvensional}

Dalam memahami perkawinan antara wanita Muslim dengan pria non-Muslim, ulama sepakat bahwasanya hukumnya haram, tetapi perkawinan antara pria Muslim dengan wanita non-Muslim ulama berbeda pendapat, hal ini disebabkan perbedaan penafsiran terhadap ayat al-Qur'an tersebut.

Ada tiga pendapat yang berkembang di kalangan ulama dalam menafsirkan ayat di atas, ${ }^{21}$ yaitu mengenai lelaki Muslim menikahi wanita Ahli Kitab. Pendapat pertama menyatakan bahwa bahwa lelaki Muslim haram menikahi wanita Ahli Kitab. Pendapat ini dikemukakan oleh Abdullah ibn Umar dengan menggunakan penafsiran terhadap surat al-Baqarah ayat 221, yang menyatakan

${ }^{19}$ Ibid, hlm. 44.

${ }^{20}$ M. Hasbi Ash Shiddieqy, Hukum-Hukum Fiqih Islam (Jakarta: PT. Bulan Bintang, 1991), hlm. 127.

${ }^{21}$ Abd. Salam Arief, Pembaruan Pemikiran Hukum Islam (Yogyakarta: LESFI, 2003), hlm. 122. 
bahwa wanita Ahli Kitab dari kalangan Nasrani dan Yahudi adalah termasuk golongan Musyrik karena menuhankan Isa ibn Maryam dan Uzer. Dengan demikian, mereka tidak halal dinikahi karena orang musyrik haram dinikahi.

Pendapat kedua dikemukakan oleh Atha' bin Rabbah. Ia menyatakan bahwa mengawini Ahli Kitab adalah rukhsah, karena saat itu wanita muslimah sangat sedikit. Sedangkan sekarang wanita muslimah telah banyak, oleh karenanya mengawini wanita Ahli Kitab tidak diperlukan lagi dan otomatis hilanglah rukhsah untuk mengawininya.

Pendapat ketiga dikemukakan oleh jumhur ulama yang membolehkan mengawini wanita Ahli Kitab berdasarkan firman Allah dalam surat al-Ma'idah ayat 5 tersebut, sedangkan yang termasuk Ahli Kitab adalah wanita-wanita dari kalangan Yahudi dan Nasrani.

Dari beberapa pendapat di atas perlu adanya pengidentifikasian siapa yang sebenarnya yang dikategorikan oleh al-Qur'an sebagai orang musyrik, yang kemudian haram dikawini oleh orang Islam. Dikatakan musyrik bukan hanya mempersekutukan Allah melainkan juga tidak memercayai salah satu dari kitab-kitab samawi, baik yang telah terdapat penyimpangan ataupun yang masih asli, serta tidak seorang nabi pun yang meraka percayai. Adapun Ahli Kitab adalah orang yang memercayai salah seorang nabi dari nabi-nabi dan salah satu kitab dari kitab-kitab samawi, baik sudah terjadi penyimpangan pada mereka dalam bidang akidah dan amalan. ${ }^{22}$

Menurut pandangan ulama di zaman modern ini, seorang pakar seperti Rasyid Ridha, murid Imam Muhammad Abduh, menegaskan bahwa Majusi, Sabian, Hindu, Buddha, Konfucius, Shinto, dan agama-agama lain dapat dikategorikan sebagai Ahli Kitab. Ridha menfatwakan bahwa laki-laki Muslim yang

${ }^{22}$ Nurcholis Madjid, dkk. Fiqih Lintas Agama (Jakarta: PARAMADINA, 2004), hlm. 159. 
diharamkan oleh Allah menikah dengan perempuan-perempuan musyrik dalam surat al-Baqarah ayat 221 adalah perempuan musyrik Arab masa lalu. Itulah pendapat mufasir Ibn Jarir alThabari. Sedangkan orang-orang Majusi, Sabian, penyembah berhala di India, Cina dan yang semacamnya, seperti orang Jepang adalah Ahli Kitab, yang mengandung paham monoteisme sampai sekarang. Karena itu, halal menikahi perempuan-perempuan mereka. ${ }^{23}$

\section{F. Perkawinan Beda Agama di Indonesia}

Perbedaan keyakinan bisa terjadi sebelum, selama, dan sesudah perkawinan. Perbedaan agama sebelum perkawinan yang berlanjut saat perkawinan akan berakibat pada perdebatan sah tidaknya perkawinan itu. Sementara perbedaan agama yang muncul selama membina dan menjalankan rumah tangga, bisa menimbulkan kontroversi pada soal pembatalan perkawinan yang bersangkutan.

Undang-Undang perkawinan relatif jelas menolak kebolehan orang berbeda agama untuk melangsungkan perkawinan, karena dianggap sah apabila kedua mempelai tunduk pada suatu hukum yang tidak ada larangan pernikahan dalam agamanya, hal ini tidak berarti lepas dari masalah. Sebaliknya, ia mengundang berbagai penafsiran. ${ }^{24}$

Penafsiran terhadap ketentuan itu akan memunculkan :. Pertama, tafsiran bahwa perkawinan beda agama merupakan pelanggaran terhadap UU No. 1/1974 pasal 2 ayat 1 jo pasal $8 \mathrm{f}$, yang menyatakan bahwa perkawinan adalah sah jika dilakukan menurut hukum masing-masing agamanya dan kepercayaannya itu. Dalam penjelasan UU ditegaskan bahwa dengan perumusan pasal 2 ayat 1 tidak ada perkawinan di luar hukum masing-masing agamanya dan kepercayaannya itu.

\footnotetext{
${ }^{23}$ Ahmad Nurcholish, Memoar Cintaku Pengalaman Empiris Pernikahan Beda Agama (Yogyakarta: LKiS, 2004), hlm. 153.

${ }^{24}$ Alyasa Abubakar, Perkawinan Muslim dengan Non-Muslim (Negro Aceh

Darussalam: Dinas Syari'at Islam, 2008), hlm. 60.
} 
Kedua, perkawinan antar-agama itu sah dan dapat dilangsungkan karena telah tercakup dalam perkawinan campuran. Alasannya, pasal 57 tentang perkawinan campuran yang menitikberatkan pada dua orang yang di Indonesia tunduk pada hukum yang berlainan. Ini berarti pasal ini mengatur perkawinan antara dua orang yang berbeda kewarganegaraan juga mengatur dua orang yang berbeda agama.

Ketiga, perkawinan antar-agama sama sekali tidak diatur dalam UU No. 1/1974, sehingga berdasarkan pasal 66 UU No. 1/1974, persoalan perkawinan beda agama dapat dirujuk pada peraturan perkawinan campuran, karena belum diatur dalam undang-undang perkawinan. ${ }^{25}$

Secara normatif, perkawinan beda agama dalam KHI dibagi menjadi tiga. ${ }^{26}$ Pertama, perbedaan agama sebagai kekurangan syarat perkawinan. Perbedaan agama yang terjadi dan diketahui sebelum akad nikah diatur dalam bab VI mengenai Larangan Kawin (Pasal 40 dan 44), serta bab X mengenai Pencegahan Perkawinan (Pasal 61). Seorang pria dilarang melangsungkan perkawinan dengan wanita yang tidak beragama Islam (Pasal 40 c), sementara seorang wanita Islam dilarang melangsungkan perkawinan dengan seorang pria yang tidak beragama Islam (Pasal 44). Memang bagian ini secara harfiah terpisah dari ketentuan mengenai rukun dan syarat perkawinan, namun pasal 18 menjelaskan bahwa sesungguhnya bab VI ini memiliki hubungan dengan bab IV bagian kedua mengenai calon mempelai.

Kedua, perbedaan agama sebagai alasan pencegahan perkawinan. Pencegahan tidaklah memiliki konsekuensi bagi absah tidaknya pernikahan, karena tidak/belum terjadi akad nikah (Pasal 61), pencegahan diajukan kepada Pengadilan Agama dalam daerah hukum di mana perkawinan akan dilangsungkan dengan memberitahukan kepada PPN setempat (Pasal 65). Yang dapat

${ }^{25}$ Khairil Anwar, "Perkawinan Beda Agama Menurut Hukum Positif Indonesia", (www.makalahnet.blagspot.com, diakses 12 Desember 2017).

${ }^{26}$ M. Karsayuda, Perkawinan Beda Agama (Yogyakarta: Total Media, 2006), hlm. 136 
mengajukan pencegahan adalah keluarga dalam garis keturunan ke bawah, saudara, wali nikah, wali pengampu dari pihak mempelai (Pasal 62). Suami atau istri yang masih terikat dalam perkawinan dengan salah satu calon mempelai dapat mengajukan pencegahan perkawinan (pasal 63). Bahkan, pejabat yang bertugas mengawasi perkawinan berkewajiban mencegah perkawinan bila rukun dan syarat perkawinan tidak terpenuhi (Pasal 64).

Ketiga, beda agama sebagai alasan pembatalan perkawinan. Pasal 75 bagian dari pasal-pasal yang mengatur tentang pembatalan perkawinan, yang salah satu alasan pembatalannya adalah "salah satu dari suami istri murtad". Keputusan pembatalan perkawinan karena alasan salah satu dari suami istri murtad, tidak berlaku surut.

\section{G. Peraturan tentang Perkawinan antar-Agama di Negara Muslim Lain (Kontemporer)}

Dalam praktik perkawinan antar-agama, negara-negara Arab banyak yang membiarkan terjadinya perkawinan Islam, perempuan Kristen atau Yahudi menikah dengan pria Muslim tetapi tidak untuk pria non-Muslim dengan perempuan muslimah.

Di Turki, pernikahan antar-agama tidak hanya diperbolehkan bagi pria Muslim dengan Ahli Kitab, tetapi juga untuk pria nonMuslim melalui hukum sekuler. Sedangkan di Malaysia nonMuslim harus mengkonversi Islam dalam rangka untuk menikahi seorang Muslim. Sehingga, pernikahan tunduk pada satu hukum yaitu Islam.

Pernikahan antar-agama, terutama antara Hindu dan Muslim, sering kali menjadi rebutan dan telah mengakibatkan kerusuhan komunal di India. Karena ada klaim banyaknya kegiatan ekstrem dalam upaya perekrutan agama dengan jalan perkawinan. $\underline{\text { Cinta }}$ jihad yang dipraktikkan oleh para Islamis terhadap non-Muslim terutama pada gadis-gadis Hindu, yang ditargetkan untuk konversi 
ke agama Islam dengan berpura-pura cinta pada perempuan nonMuslim tersebut. ${ }^{27}$

\section{H. Analisis Kawin beda agama dalam praktek}

Tanpa membedakan antara perkawinan beda agama yang memungkinkan diakui berdasarkan pendapat tertentu di kalangan Islam, maupun yang sama sekali tidak memungkinkan mendapat pengakuan, terdapat gambaran bahwa perkawianan beda agama cenderung mengalami peningkatan, baik secara nasional maupun regional/lokal. ${ }^{28}$

Di Kota besar Indonesia perkawinan beda agama menunjukan kecenderungan meningkat dari tahun ke tahun, di DKI Jakarta 1974 ada 10 kasus, tahun 1979 ada 80 kasus, tahun 1980 ada 99 kasus dan pada tahun 1985 ada 617 kasus. Pada tahun 1984 Keuskupan Agung Jakarta terjadi perkawinan beda agama sebanyak 2.035 kasus, $163(8.01 \%)$ diantara salah satu pasangan beragama Islam. Sementara perkawinan beda agama antara lakilaki muslim dengan wanita kitabiyah yang terjadi pada KUA di Jakarta relatif kecil. Pada tahun 1986 ada 19 kasus, 1987 terjadi 25 kasus, 1988 terjadi 32 kasus, 1989 terjadi 42 kasus, 1990 ada 30 kasus. Selain di KUA, pada kantor catatan sipil (KCS) DKI Jakarta juga berlangsung perkawinan beda gama laki-laki muslim dengan perempuan non muslim. ${ }^{29}$

Kawin beda agama berpotensi melahirkan persoalan hukum, antara lain :

1. Soal keabsahan perkawinan yang akan menimbulkan hak dan kewajiban antara suami istri. Hak istri terdapat nafkah dan harta bersama sepenuhnya tergantung kepada ada tidaknya perkawinan yang sah sebagai alasan hukumnya. Begitu pula perkawinan yang sah akan menimbulkan anak-anak yang sah. Anak perkawinan yang tidak sah mempunyai hubungan hanya dengan ibunya. Dengan demikian segala hak anak terhadap

\footnotetext{
${ }^{27}$ Wikipedia, Pernikahan antar-Agama dalam Islam, Ensiklopedia bebas, 2009.

${ }^{28}$ M.Karayuda, perkawinan beda agama, total Media, yogyakarta,2006. 87

29 Ibid. 88
} 
bapaknya akan hilang dan tidak diakui oleh hukum. Hak pemeliharan terhadap anak yang dimiliki orang tuanya, hanya akan dapat diperoleh apabila perkawinannya sah. Sebaliknya, perkawinan beda agama yang memiliki bukti otentik berupa buku nikah, dapat diajukan pembatalan dengan alasan bahwa pernikahan tidak sah. Kerena tidak sesuai dengan hukum agama (hukum Islam) sebagaimana diatur pada pasal 40 huruf c Kompilasi Hukum Islam. Pembatalan nikah , walaupun tidak berlaku surut, tetapi akan menimbulkan problem kejiwaan yang besar bagi anak yang dilahirkan dari perkawinan yang dibatalkan tersebut.

2. Hak kewarisan antara suami istri dan anak-anaknya. Sekiranya ke absahan perkawinan pasangan beda agama tidak dipersoalkan, dan dianggap keduanya telah terikat dalam perkawinan yang sah. Begitu pula status anak-anaknya dengan sendirinya juga diangap sah, namun hak waris diantara mereka tidak ada. Perbedaan agama bisa mengugurkan hak saling mewarisi, bila persoalan warisan diatas dilihat aspek keadilan, maka larangan kawin beda agama jelas lebih melindungi hak kewarisan masing-masing. Anak-anak tidak mungkin beragama kembar, karena agama merupakan keyakinan. Konsekwensinya anak hanya seagama dengan salah satu dari kedua orang tuanya. Ketika anak seagama dengan bapaknya yang mendapatkan hak kewarisan dari bapaknya itu, berhadapan dengan saudaranya yang beda agama. Akan timbul persoalan keadilan ketika yang satu-yang seagama-mendapat warisan, sementara saudara kandungnya-anak pewaris yang lain- yang tidak seagama, sama sekali tidak mendapatkan warisan.

3. Masalah pengadilan tempat menyelesaikan sengketa rumah tangga. Lembaga peradilan di Indonesia selain mengenal kewenangan absolut dan kewenangan relatif, juga mengenal azas personalitas. Pengadilan agama berwenang terhadap pihak-pihak yang beragama Islam, sementara pengadilan negeri berwenag terhadap pikah-pihak yang bukan muslim. 
Terhadap pasangan yang berbeda dimungkinkan terjadi sengketa kewenangan mengadili yang ada pada mahkamah agung. Bila hal ini yang harus ditempuh lebih dahulu, maka pokok perkara akan dikesampingkan sementara, dan kan diselesaikan kemudian. Penyelesaina sengketa diantara mereka menjadi lambat dan berbelit-belit.

Berdasarkan dari bacaan di atas, maka dapat ditarik sebuah analisis terhadap suatu permasalahan perkawinan beda agama, yang sesuai dengan zaman sekarang sehingga dapat ditarik suatu kesimpulan dalam makalah ini, bahwa perkawinan beda agama pada zaman sekarang berbeda dengan tujuan perkawinan antaragama zaman dahulu yakni zaman Nabi Muhammad saw.

Perkawinan yang berdasarkan perbedaan agama atau keyakinan, maka ulama ikut angkat bicara dalam memutuskan hukum perkawinan tersebut, terlebih dalam agama Islam. Ulama sepakat bahwasanya menikahi orang musyrik dan kafir hukumnya haram. Sedangkan dalam masalah menikahi Ahli Kitab yakni Nasrani dan Yahudi, ulama merujuk surat al-Ma'idah ayat 5 bahwa pria non-Muslim dilarang menikahi wanita muslimah, tetapi pria Muslim boleh menikahi wanita Ahli Kitab.

Pria Muslim boleh menikahi wanita Ahli Kitab, ini dengan dalih mengikuti Rasul saw. yang kedua isri beliau adalah wanita Ahli Kitab, yakni Safiyah dan Mariatul Qibtiyah. Bukan itu saja pria adalah kepala rumah tangga yang memimpin keluarga sehingga diharapkan mampu membawa istri masuk Islam.

Akan tetapi, pada kenyatannya wanitalah yang mengurus anakanak dari hasil perkawinan tersebut sehingga ibu mendominasi pemikiran anak. Mudah bagi ibu Ahl Kitab membawa anakanaknya memeluk agama yang dianutnya. Menurut sebagian ulama, Yahudi dan Nasrani (Kristen) bukanlah Ahl Kitab karena sudah menyimpang ajarannya, bahkan ada yang mengatakan bahwa Yahudi dan Nasrani adalah orang kafir dan musyrik yang tidak boleh dinikahi, karena mereka mengakui Uzair dan Nabi Isa sebagai anak Allah. 
Di Indonesia terdapat enam agama yang diakui, yaitu Islam, Kristen Katolik, Protestan, Buddha, Hindu, dan Khonghucu. Dari lima agama ini hanya dua agama yang termasuk agama samawi, yaitu Kristen Katolik dan Protestan, karena mereka mengikuti agama Nasrani. Sedangkan yang lain tidak termasuk Ahli Kitab sehingga dikategorikan sebagai musyrik. Maka, semakin jelas bahwa menikahi pemeluk agama lain di Indonesia dilarang, walaupun Kristen Katolik dan Protestan termasuk Ahli Kitab, tetapi meraka sudah menyimpang. Dengan demikian, bisa ditarik kesimpulan bahwa Ahli Kitab sudah tidak ada.

Perkawinan beda agama menurut UU perkawinan Indonesia tidak diperbolehkan karena selain adanya larangan dari agamaagama di Indonesia, Undang-undang Nomor 1 tahun 1974 dan Kompilasi Hukum Islam, juga terdapat mudarat yang sebabkan perkawinan antar-agama seperti rantan perceraian, dua kepala rumah tangga, dan adanya pihak yang dirugikan.

Hal ini sesuai dengan keputusan para ulama di Indonesia baik Majelis Ulama Indonesia (MUI), Nahdlatul Ulama (NU), dan PP Muhammadiyah. MUI memutuskan, pertama, bahwa perkawinan wanita Muslim dengan laki-laki non-Muslim hukumnya haram. Kedua, seorang laki-laki Muslim diharamkan mengawini wanita bukan Muslim. Perkawinan antara laki-laki Muslim dengan wanita Ahlul Kitab memang terdapat perbedaan pendapat. "Setelah mempertimbangkan bahwa mafsadatnya lebih besar dari maslahatnya, MUI memfatwakan perkawinan tersebut hukumnya haram," ungkap Dewan Pimpinan Munas II MUI, Prof Hamka, dalam fatwa itu. ${ }^{30}$

Terjadinya perkawinan beda agama dianggap bertentangan dengan tujuan perkawinan, bagaimana mungkin mampu menciptakan keluarga yang sakinah, mawaddah, dan rahmah kalau masing-masing pasangan berbeda keyakinan. Dalam

${ }^{30}$ Heri Ruslan, "Hukum Nikah Beda Agama dalam Islam dan Kristen, Samakah?" (www.repoblikaonline.go.id, diakses 10 April 2012). 
perspektif sadd az-zari'ah, ${ }^{31}$ perkawinan beda agama dilarang karena dikhawatirkan bisa merusak eksistensi iman seseorang. MUI, Majlis tarjih PP Muhammadiyah, dan ulama NU melarang perkawinan beda agama atas dasar menutup kemungkinan mudarat yang akan terjadi sebagai akibat perkawinan beda agama. Pelarangan ini juga mendapatkan momentum ketika dihubungkan dengan wacana Kristenisasi yang marak saat ini. ${ }^{32}$

Perkawinan beda agama zaman sekarang tidak sesuai dengan tujuan perkawinan antar-agama pada zaman Nabi Muhammad saw., sekarang perkawinan antar-agama hanya sebagai pembuktian gengsi dan pemuas nafsu belaka bukan untuk kejayaan agama Islam sehingga hal ini lebih baik dihindari.

\section{Penutup}

Perkawinan beda agama (ahli kitab) diperbolehkan, berlaku bagi laki-laki Muslim menikah dengan wanita Ahli Kitab tapi tidak berlaku sebaliknya, karena nabi Muhamad pernah menikah dengan ahli kitab (Safiyah Binti Huyay Bin Aktab dan Mariatul Kibtiyah). Menurut ulama madern yang dimaksud ahli kitab adalah Majusi, Sabian, Hindu, Budha, konfucius, Shinto dan agama-agama lainnya. Adapun yang dimaksud perempuan-perempuan musrikah dalam surat al Baqarah ayat 221 adalah perempuanbmusyrik arab masa lalu.

\footnotetext{
${ }^{31}$ Sadd adz-dzari'ah adalah memotong jalan kerusakan sebagai upaya menghindari kerusakan tersebut, Meski suatu perbuatan bebas dari unsur kerusakan, namun jika perbuatan itu merupakan jalan atau sarana terjadinya suatu kerusakan, maka diharuskan mencegah perbuatan tersebut.

${ }^{32}$ Masdar F. Mas'udi, "Meletakkan Kembali Maslahah Sebagai Acuan Syari'at”, Jurnal Ulumul Qur'an, No. 3 vol: IV, (Jakarta: PARAMADINA, 1995), hlm. 97
} 


\section{DAFTAR PUSTAKA}

Abubakar, Alyasa, Perkawinan Muslim dengan Non-Muslim

(Negro Aceh Darussalam: Dinas Syari'at Islam, 2008)

Al Jabry, Abdul Mutaal Muhammad, Pernikahan Campuran Menurut Pandangan Islam, terj. Achmad Sathori (Jakarta: PT. Bulan Bintang, 1988)

Al Maragi, Ahmad Mustofa, Tafsir al Maragi (Mesir Al Babi Al Habibi, 1394H/1974) terj. K.Anshori Umar Sitanggal dkk)

Al-Wahidi, Asbab al-Nuzul (Kairo: Dar al-Ittih \}ad al-'Arabi li alTab'ah, 1968)

Anwar,Khairil, "Perkawinan Beda Agama Menurut Hukum Positif Indonesia", (www.Makalahnet.Blagspot.com, diakses 12 Desember 2011).

Arief , Abd. Salam, Pembaruan Pemikiran Hukum Islam (Yogyakarta: LESFI, 2003)

Ash Shiddieqy, M. Hasbi, Hukum-Hukum Fiqih Islam (Jakarta: PT. Bulan Bintang, 1991)

Depag RI, al Qur'an dan terjemah (Gema Risalah press Bandung, 1989)

Faridl, Miftah, Masalah Nikah dan Keluarga (Jakarta: Gema Insani Press, 1999)

Heri Ruslan, "Hukum Nikah Beda Agama dalam Islam dan Kristen, Samakah?" (www.RepoblikaOnLine.go.id, diakses 10 April 2012).

Ibnu Hazm, al muhallah, vi,Bairut;dar-al fikr. 449

M. Karsayuda, Perkawinan Beda Agama (Yogyakarta: Total Media, 2006)

Madjid, Nurcholis, dkk. Fiqih Lintas Agama (Jakarta:

PARAMADINA, 2004)

Mas'udi , Masdar F., "Meletakkan Kembali Maslahah Sebagai Acuan Syari'at", Jurnal Ulumul Qur'an, No. 3 vol: IV, (Jakarta: PARAMADINA, 1995) 
Nurcholish, Ahmad, Memoar Cintaku Pengalaman Empiris Pernikahan Beda Agama (Yogyakarta: LKiS, 2004)

O.S. Eoh, Perkawinan antar-Agama dalam Teori dan Praktek (Jakarta: PT. Raja Grafindo Persada, 1996)

Purwaharsanto pr, Perkawinan campuran Antar Agama menurut UU RI No. 1 Tahun 1974 tentang perkawinan: Sebuah Telaah Kritis Aktualita Media Cetak (Yogyakarta: tnp, 1992)

Rasyid Ridha, Tafsir al-manar, VI,Mesir,1952

Rida, Muhammad Rasyid, Tafsir al-Manar, jilid II (Beirut: Dar al-Fikr, 1957)

Shihab , M. Qurais, Ahli kitab dalam Wahyu Nafis, ed.

Rekontruksi dan religius Islam

(Jakarta;Paramadina,1969)

Suhadi, Kawin Lintas Agama Perspektif Kritik Nalar Islam

(Yogyakarta: LKiS, 2006)

Wikipedia, Pernikahan antar-Agama dalam Islam, Ensiklopedia bebas, 2009 